\title{
GLL
}

G0 Geomatics, Landmanagement and Landscape No. $2 \cdot 2019,55-62$

\section{CONSTRUCTING THE 3D MODEL OF A GLACIER PART ON THE GALINDEZ ISLAND}

\author{
Volodymyr Hlotov, Myroslava Biala
}

\begin{abstract}
Summary
The publication is based on the research carried out at the Ukrainian Polar Station "Academic Vernadsky", located in the Antarctic region at the Galindez Island. The article establishes relationships between global climate change and changes occurring in the area of Galindez Island based on 3D models of the glacier surface. The article has two parts. The first one reviews software products (AutoCAD, ArcGIS, SketchUp, Digitals) used for three-dimensional surface modeling. We analyze their characteristics, and emphasize the advantages and disadvantages of each program for the purpose of terrestrial 3D modeling. In the second, experimental part of the research, we present 3D models of the glacier surface constructed using various software products. The result of the research presents the obtained model of Galindez Island including all relevant textures and buildings.
\end{abstract}

\section{Keywords}

glacier • digital camera $\bullet$ 3D modelling $\bullet$ GIS $\bullet$ topographical plan

\section{Introduction}

In recent decades, the issue of climate change has gained global significance, not only causing changes in average annual temperatures but also imbalances within ecosystems, changes in the atmosphere, cryosphere, and hydrosphere. Observation of the landscape change in the Antarctic ice sheets plays an important role in exploration of this issue [Oza et al. 2011]. The decrease in glacial masses is accompanied by the global rise of sea level, which can lead to the flooding of large coastal areas. Furthermore, the volume and mass of the glacier have an impact on the velocity of the Earth's rotation, and its gravitational field.

The most considerable warming on the Earth surface had been recorded in the Antarctic Peninsula area in 2001-2007. According to observation data [Bakhmutov et al. 2017] at the "Academic Vernadsky" station, located on the Galindez Island territory, the average annual temperature increases at a rate of $0.56^{\circ} \mathrm{C}$ per the decade accumulating to a total of $3^{\circ} \mathrm{C}$ temperature rise over the last 50 years. The area of the ice shelf since 1950 decreased by 8 thousand $\mathrm{km}^{2}$. 
Monitoring of the landscape changes in the Antarctic continent allows for an assessment of the anthropogenic impact on Earth's ecosystems, as well as climatic, hydrological and glaciological changes. Based on research carried out in the region, it is possible to predict future trends in the global climate change [Yun et al. 2008, Hlotov et al. 2003].

Considering the peculiar features of the landscape, it is important to account for its intrinsic dynamics of change, providing significant information about the general characteristics of the object. In the scientific and technical analysis of the change [Hlotov et al. 2003], researchers indicate historical data from previous studies of the volume changes to glaciers, which are located near the "Academician Vernadsky" Ukrainian Antarctic station on the Galindez Island. The methods used by scientists also made it possible to provide ex-ante results of the accuracy assessment.

Partial 3D modeling of the glacier is an important stage of the process aimed at the accumulation of previously collected data [Bennett et al. 2009, Fallourd et al. 2010, Knizhnikov et al. 2009], improvement of its processing, and a better understanding of the spatiotemporal dynamics.

\section{Software products analysis in the field of 3D modeling}

Three-dimensional relief models, defined as the digital and mathematical relief representations of a certain territory on the discrete set of outbound points basis make it possible to virtually recreate the real surface and its structure with a given accuracy. This task can be realized using special software and technologies. A number of software products were analyzed considering the features of the research object, including AutoCAD, ArcGIS, SketchUp, and Digitals.

AutoCAD software enables the creation of three-dimensional models based on two-dimensional drafting by using the $3 \mathrm{D}$ modeling function from the working space. AutoCAD supports two types of surfaces: procedural and NURBS. Procedural surfaces use the possibilities of associativity of surfaces and defining their setpoints, while NURBS surfaces enable the use of sculptures by managing peaks.

The product applies three-dimensional print management by using the Print Studio. However, we should take into account the program's disadvantages: the difficulty of linking information data to objects, the need for powerful PC resources for optimal work in the program, the lack of opportunities for creating relief from the TIN network, and specialized data needed to create a 3D model. In addition, in the AutoCAD environment, the surface model is a thin shell that has no mass or volume.

ArcGIS is a GIS software used for land cadaster, geodesy, and land management. Particular attention should be paid to ArcMap, 3D Analyst, and ArcScene applications. The first application is used to create maps, to analyze and edit them. The other two allow the user to create 3D models, to analyze surfaces, and to edit them in a variety of ways, and to create raster data. The benefits of this software include a large number of geolocation tools (conversion, overlay analysis, multilayer map organization), the ability to work in multiple applications at once by importing and exporting the necessary files between applications, and support of various file formats. 
SketchUp is Trimble Navigation software released in two versions: SketchUp Pro is a paid version, and SketchUp Make is a free version. Initially, the software was aimed as a tool for the rapid prototyping of interiors, furniture and buildings, but over time it has developed advanced functionality, which makes it possible to effectively work with three-dimensional graphics. SketchUp works with texturing at the basic level, which, combined with a simple and intuitive interface, makes it easy to master for beginners. The program's weaknesses include limited functionality and the initial orientation to work with structures and interiors.

The Digitals is a software product by Geosystem, designed to solve the problems with digital cartography and land management. The Digitals is delivered to users in two formats: Digitals Standard and Digitals Professional. The program contains a library of symbols (point, line, plane), which facilitate the creation of a digital map. The graphics core of the program is used in digital photogrammetric stations Delta. With raster image vectorization function, we can use scanned maps and single images in .tiff and .bmp formats. There is an opportunity to automatically download geo-linked space images from Google Maps or Microsoft Virtual Earth. There are also functions for working with relief, which enable the creation of regular DEM with pickets and/or isolines, to model isolines, to assign a height to all objects on the map pickets and/or isolines and to calculate volumes. The program has some disadvantages: slow processing of large-scale plans and "freezing" when processing a large number of map layers.

\section{Research dataset}

During the XVIII seasonal Antarctic expedition, digital stereophotogrammetric surveying of the western and southern outlet glacier on the Galindez Island from a stable base on the Winter Island was carried out. In order to analyze the accuracy of the complex method, the scientists conducted an approbation of the terrestrial laser scanner Faro Focus 3D, applying it to scan the above-mentioned glacial outputs. The complex methodology application enabled obtaining a complete digital elevation model, and provided reference and control points for the digital images orientation (Fig. 1).

Based on this research, a topographic plan in the scale 1: 1000 of the Ukrainian Antarctic station Academician Vernadsky (Galindez, Winter and Skua Islands territory) was created in the Digitals software workspace (Fig. 2). The plan was used as the basis for creating a three-dimensional model of the given area.

\section{Experimental part}

Considering the specific data format of the topographic plan, the work started from creating a $3 \mathrm{D}$ model of the given territory in the Digitals software.

In order to model the relief, it was necessary to analyze the layers included in the large-scale topographical plan. In the presence of a large dataset included in the plan, the 3D model of the territory may be incorrectly displayed (Fig. 3). 


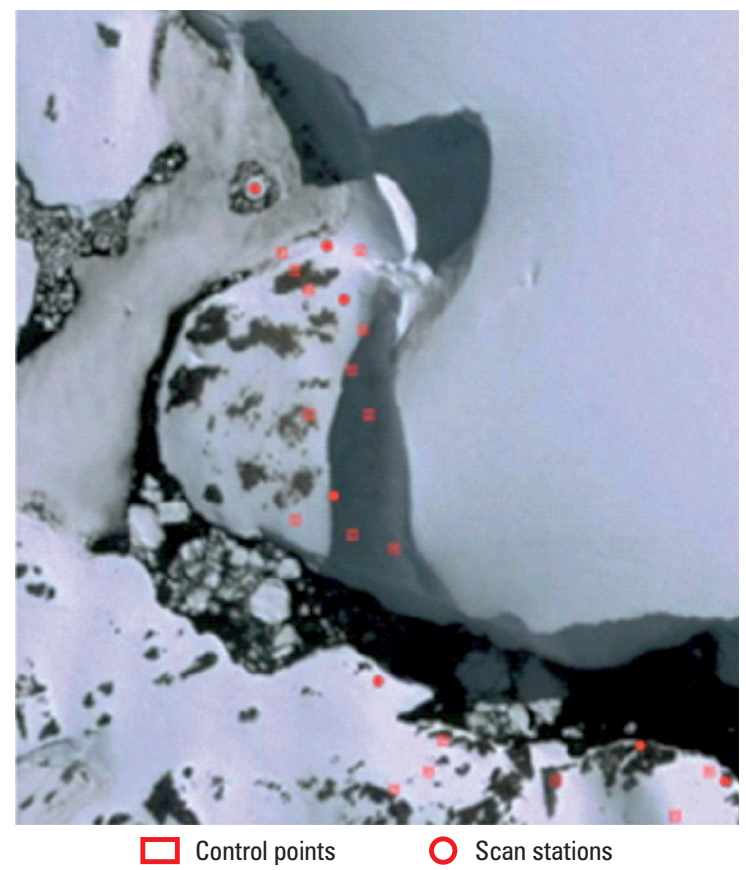

Fig. 1. Control marks location scheme and scanning stations of the Galindez Island glacier

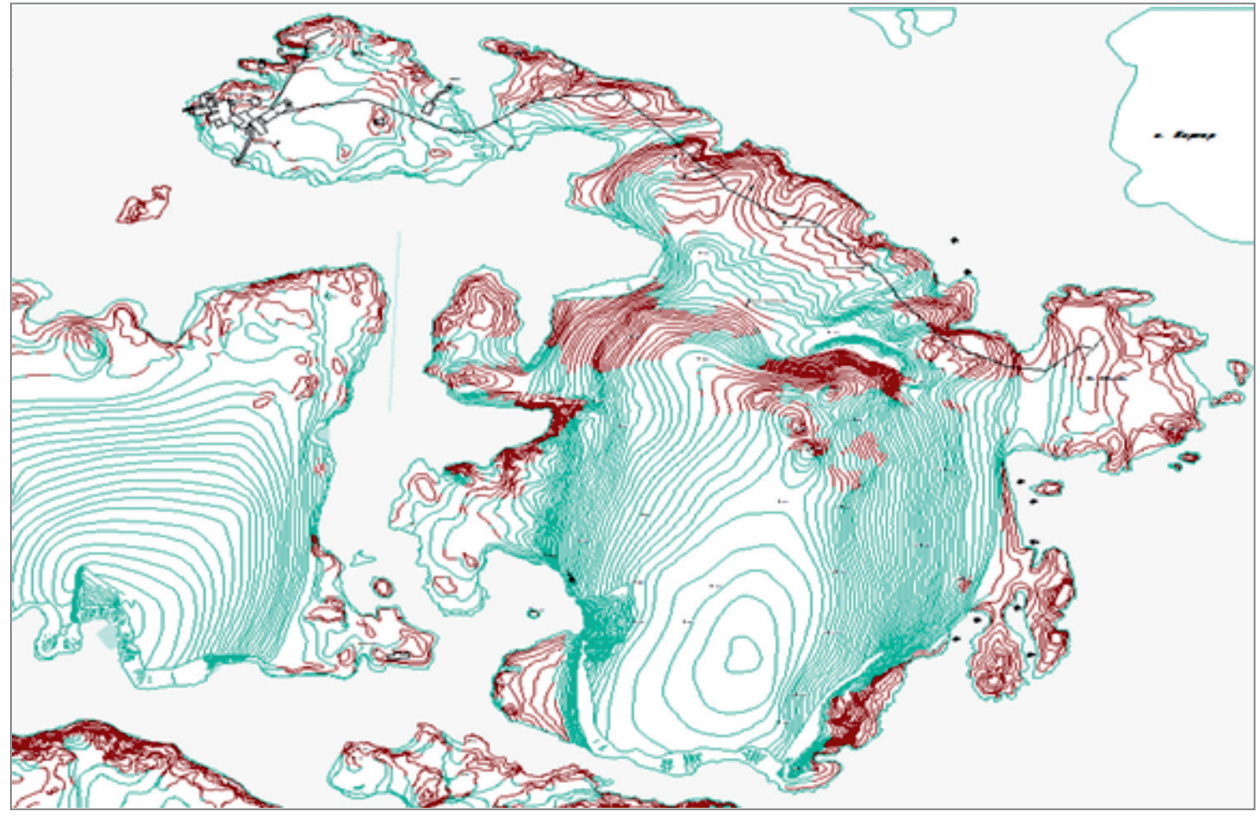

Fig. 2. A topographic plan fragment modeled in the Digitals software environment 


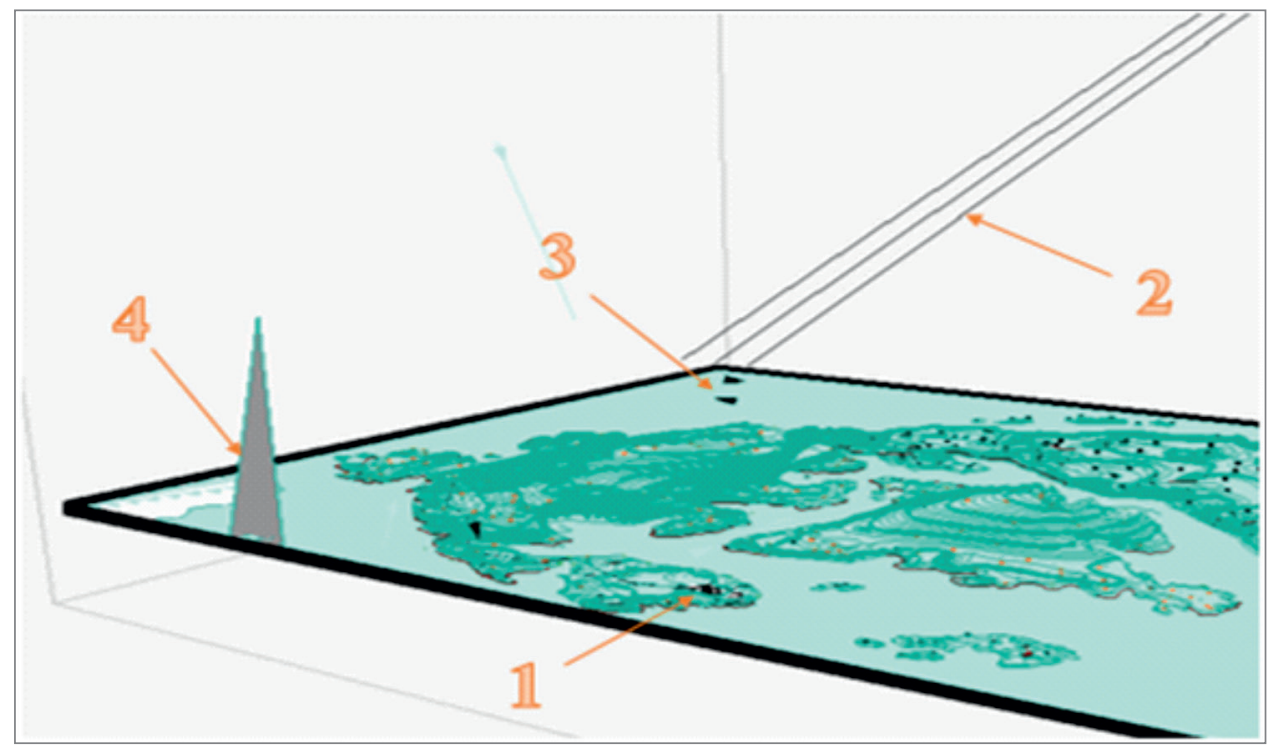

Fig. 3. Preliminary display of the three-dimensional model without excluding incorrectly displayed data (1, 3 - point symbols, 2 - regular kilometer grid, 4 - other territories)

As we can see, the constructed three-dimensional model doesn't satisfy the performance conditions of the task. It contains inaccurate data that distorts the display of the model, and it does not allow to clearly reflect the necessary information. In order to solve the problem, it is necessary to classify the layers of a large-scale topographical plan, and to hide the layers that distort the 3D model.

Concealing some of the layers allows highlighting visibility of different types of isolines, contours of the territory, coastline, soil surface, cliffs, pickets, and several other layers. Thus, the three-dimensional view of the large-scale topographic plan of the glacier on Galindez Island was redesigned and displayed as realistically as possible (Fig. 4).

As a result, the three-dimensional relief model still contains certain data that is incorrectly displayed but impossible to exclude because it carries important information about the surveyed area. In order to solve these problems, the data was split into several blocks and exported in the ${ }^{*}$.shp format with the possibility to be imported to other software products that have been analyzed. By using the ArcGIS ArcMap application, the previously discrete layers of data were data merged and used to build DEM (Fig. 5) into a given area.

To incorporate the surface structure, space images were superimposed on DIM in the Surfer software environment, with the addition of three-dimensional projection of buildings located on the island (Academic Vernadsky station). Thus, the three-dimensional model of the glacier's territory was obtained (Fig. 6). 


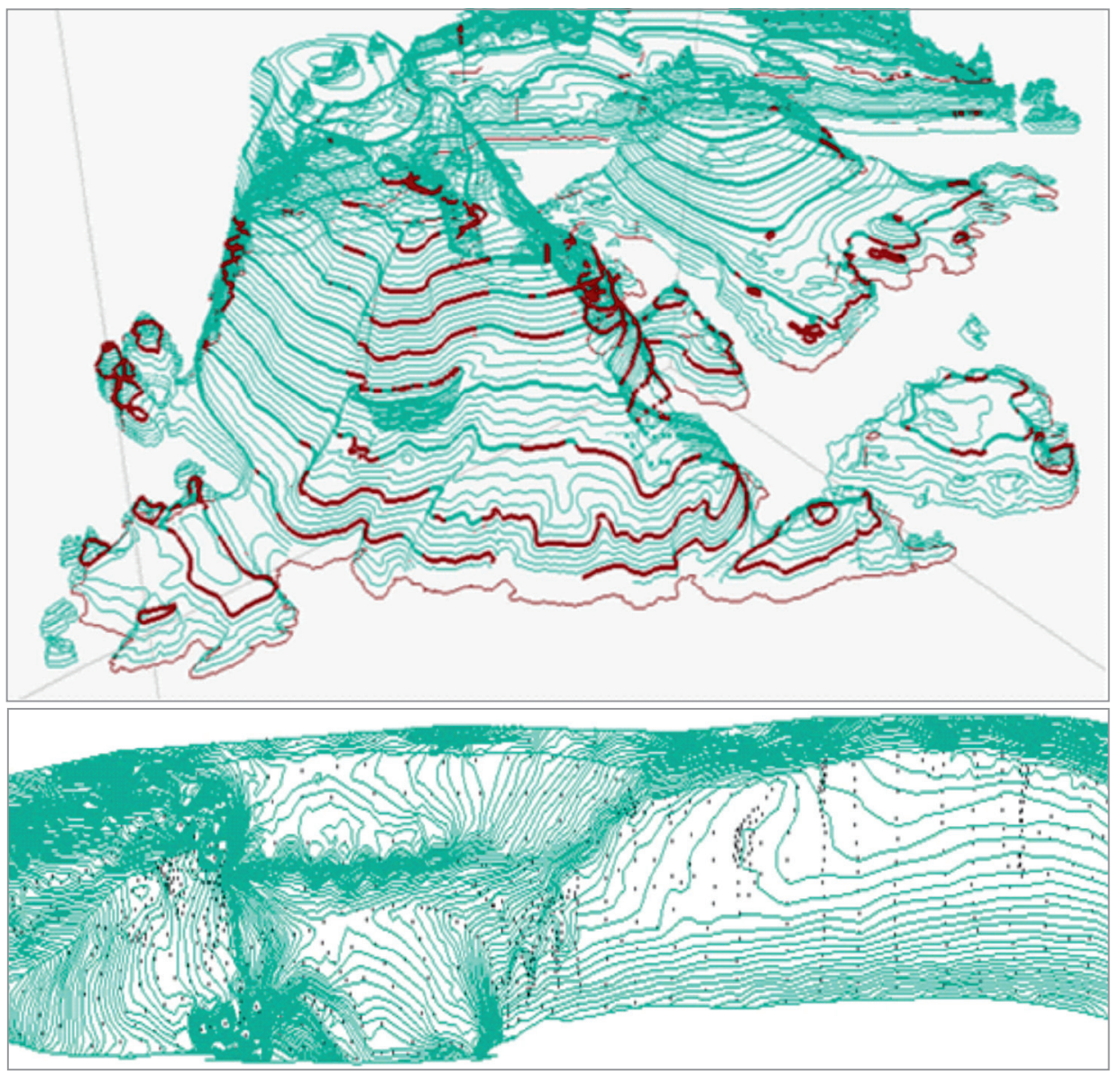

Fig. 4. A fragment of a three-dimensional relief model with the exclusion of data that was displayed incorrectly

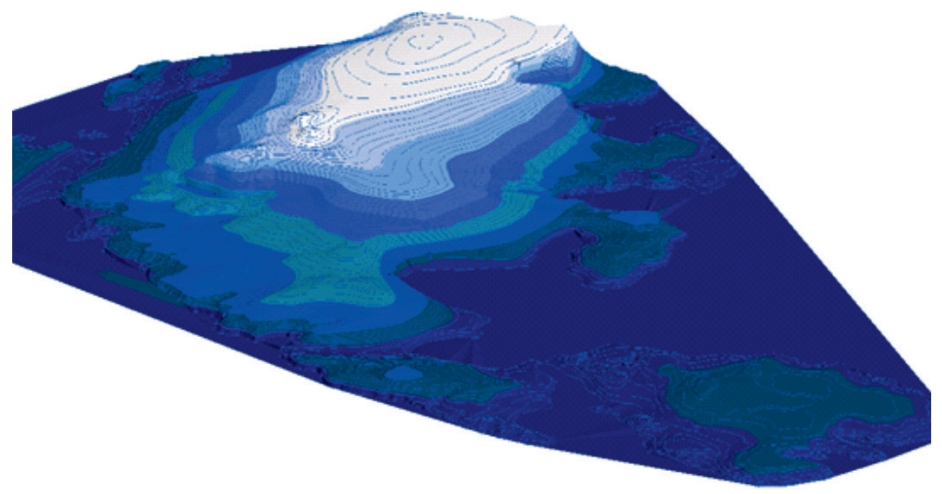

Elevation

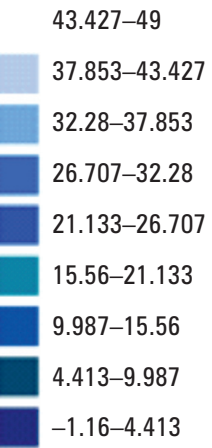

Fig. 5. DEM of the Galindez Island created in the ArcGIS package 


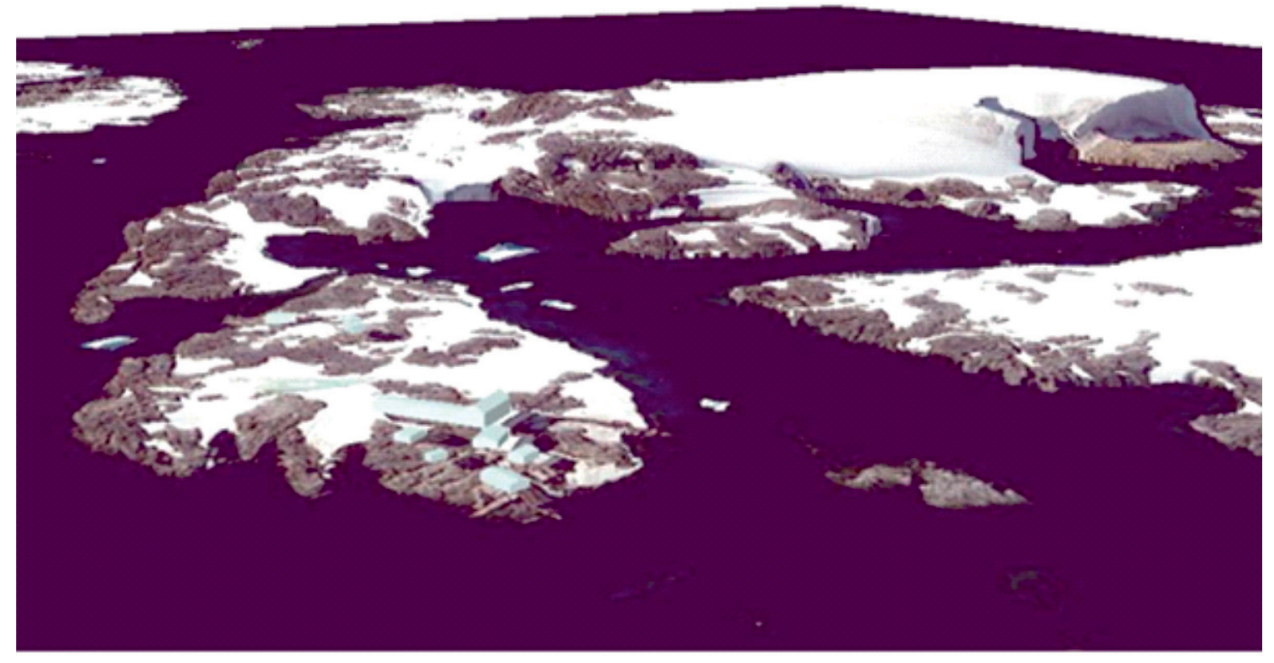

Fig. 6. The final 3D model with superimposed textures and buildings

\section{Conclusions}

The article emphasized the significate of the relationships between global climate change and the landscape change of the Antarctic continent, which allows predicting the further course of global climate processes. A three-dimensional model was created in order to visualize changes and accumulate data about the surface of the "Academician Vernadsky" Ukrainian Antarctic station.

The research included a review of surveying methods and approaches to creating a large-scale topographic plan of the Galindez Island, which served as the basis for the $3 \mathrm{D}$ model construction, and analysis of the software packages used for three-dimensional modeling. As a result of the analysis, the advantages and disadvantages of each of these programs were identified, and the optimal way to apply each of the products for the realization of the necessary goals was suggested.

As a result of the data exclusion, a new 3D model of Galindez Island was built. This allowed displaying isolines of the surfaces, which are covered, and those which are not covered by ice, breaks, coastline and other layers of a large-scale plan in a threedimensional space. At the next stage, data were exported to ArcGIS and the digital elevation model was constructed, with changes displayed by gradation of colors. In order to make the model more informative, its texture was superimposed by using space images, and three-dimensional buildings were added.

Further research is required to improve data model contents, to eliminate inaccurate surface mapping, to resolve issues with data conversion, and to create dynamic $3 \mathrm{D}$ models that reflect landscape changes in time and space. 


\section{References}

Bakhmutov V.H., Tretiak K.R., Maksymchuk V. Yu., Hlotov V.M., Hreku R.Kh., Yehorova T.P., Zalizovskyi A.V., Koloskov O.V., Korchahin I.M., Pronenko V.O. 2017. Structure and dynamics of geophysical fields in Western Antarctica [Структура і динаміка геофізичних полів у Західній Антарктиці]. Lviv Polytechnic Publishing House, Lviv, 154-178.

Bennett R.M., Pettit C., Aurambout J.P., Sheth F., Senot H., Soste L., Sposito V. 2009. Visualizing climate change impact with ubiquitous spatial technologies. The International Archives of the Photogrammetry, Remote Sensing and Spatial Information Sciences, Congress ISPRS, 38, II, 461-466.

Fallourd R., Vernier F., Friedt J.-M., Martinc G., Trouvé E., Moreau L., Nicolas J.-M. 2010. Monitoring temperate glacier with high resolution automated digital cameras - application to the Argentière glacier. ISPRS Commission III Symposium, Paris, France, 19-23.

Grosswald M.G. 2009. Ice sheets of the Russian North and North-East during the last Ice Age. Materials of glaciological research [Оледенение Русского Севера и Северо-Востока в эпоху последнего великого похолодания. Материалы гляциологических исследований], 106, Moscow.

Hlotov V.M., Kovalenok S.B., Mylynevskyi H.P., Nakalov E.F., Fulitka Yu.V. 2003. Monitoring of small icebergs as indicators of climate change in the Antarctic Peninsula [Мониторинг малых ледников как индикаторов изменений климата в районе антарктического полуострова. Ukrainian Antarctic Journal [УАЖ], 1, 93-98.

Knizhnikov Yu.F., Kravtsova V.I., Volodicheva N.A., Zolotaryov E.A., Labutina I.A., Oleynikov A.D., Khar'kovets E.G. 2009. Half a century on Elbrus. Technology of map-based and aerospace monitoring of glaciers: yesterday, today and tomorrow. Materials of glaciological research [Полвека на Эльбрусе. Технологии картографо-аэрокосмического мониторинга оледенения вчера, сегодня и завтра. Материалы гляциологических исследований, выпуск], 107, Moscow, 51-56.

Oza S.R., Singh R.K.K., Vyas N.K., Sarkar A. 2011. Study of inter-annual Ku-BAND backscatter variations of amery ice shelf, east Antarctica. ISPRS Archives XXXVIII-8/W3 Workshop Proceedings: Impact of Climate Change on Agriculture, 633-640.

Yun, Bu Yeol Lee, Jae One Son, Howoong Lee, Young Hee. 2008. Construction of geographic informatics on king Sejong station in Antarctica using lightweight aerial photogrammetry system. The International Archives of the Photogrammetry, Remote Sensing and Spatial Information Sciences, XXXVII, B8, Beijing, 843-845.

https://www.autodesk/ [accessed: 03/2019]

https://www.arcgis.com/index.html [accessed: 03/2019]

https://www.sketchup.com/ [accessed: 03/2019]

Prof., D.Sc. Volodymyr Hlotov

University of Agriculture in Krakow

Faculty of Environmental Engineering and Land Surveying

30-198 Kraków, ul. Balicka 253a

e-mail: v.hlotov@urk.edu.pl

Myroslava Biala, student of the 2nd degree

Lviv Polytechnic National University

Institute of Geodesy

Faculty of Photogrammetry and Geoinformation systems

Ukraine, Lviv, 79000, St. Karpinskogo 6

e-mail: bialamyroslava@gmail.com 